\title{
BMR
}

\section{Development of the first polymorphic microsatellite markers for the Roman snail Helix pomatia L., 1758 (Helicidae) and cross-species amplification within the genus Helix}

\author{
A.M. Krapal, O.P. Popa, E.I. Iorgu, L.B. Cojocaru, A.F. Popa and L.O. Popa \\ “Grigore Antipa” National Museum of Natural History, Bucharest, Romania \\ Corresponding author: L.O. Popa \\ E-mail: popaluis@antipa.ro \\ Genet. Mol. Res. 15 (3): gmr.15038817 \\ Received May 17, 2016 \\ Accepted August 3, 2016 \\ Published September 19, 2016 \\ DOI http://dx.doi.org/10.4238/gmr.15038817
}

Copyright (C) 2016 The Authors. This is an open-access article distributed under the terms of the Creative Commons Attribution ShareAlike (CC BY-SA) 4.0 License

\begin{abstract}
The terrestrial snail Helix pomatia (Gastropoda: Stylommatophora: Helicidae) is one of the largest gastropod species in Europe. This species is strictly protected in some European Union countries; however, at the same time, it is also farmed and commercialized for human consumption. Here, we describe 11 microsatellite markers that are very useful in population genetic studies for assessing the status of both wild and farmed populations of this species of community interest. The microsatellites were isolated using 454 pyrosequencing technologies and 11 primer pairs were selected and used for genotyping an $H$. pomatia population and also checked for cross-species amplification on $H$. lucorum and $H$. lutescens specimens. The number of alleles per locus ranged from 3 to 13 and observed
\end{abstract}


heterozygosity was between 0.458 and 0.917 . Seven of these loci were polymorphic in H. lucorum, and four in H. lutescens. This set of nuclear markers provides a powerful tool for population genetic studies of this species of community interest, and also for closely related species. The described microsatellite markers should also facilitate the identification of populations of conservation concern.

Key words: Conservation concern; STRs; Population genetics; Helix pomatia; Helicidae; Cross-species amplification

\section{INTRODUCTION}

Helix pomatia Linnaeus, 1758 (Roman snail) (Gastropoda: Stylommatophora: Helicidae) is one of the largest terrestrial species of European gastropods, with a shell reaching $4.5 \mathrm{~cm}$ in diameter (Grossu, 1983). Its native range spreads throughout all of Central and Southern Europe, from Eastern Spain (in the West) to Russia (in the East), and from the southern part of Scandinavia to Bulgaria and Italy (Grossu, 1983; Neubert, 2011). This species is the only one in the Helix genus present in the northwestern regions of the Alps, reaching the southern part of Scandinavia (Welter-Schultes, 2012).

Due to its large size, H. pomatia is farmed for consumption, together with H. lucorum and $H$. aspersa, and is highly appreciated for its taste. H. pomatia is commonly consumed in many Mediterranean countries. Due to this high interest from a gastronomical point of view, the species has been extensively analyzed in terms of both its biology and ecology, which are important for successful rearing and reproduction of individuals in snail farms. Genetic studies, however, are relatively new and do not focus exclusively on the analysis of this species, but rather on related species in the genus Helix (e.g., Mumladze et al., 2013; Korábek et al., 2014) or on the entire Helicidae family (e.g., Korábek et al., 2015). No microsatellite markers have been described to date for $H$. pomatia, as the previously mentioned studies used other types of molecular markers. One study has tested microsatellite markers in Helicella itala and $H$. pomatia (Wirth, 2000); however, of the six tested loci, only three have yielded one or two alleles when tested in two $H$. pomatia individuals.

Microsatellite markers are a great tool for assessing genetic diversity, dynamics, and structure of populations. Population genetic studies will be useful in assessing populations of this particular species, and in identifying potentially threatened ones. This will be especially important in those countries where the species is of conservation concern, but can also be useful for determining the genetic characterization of farmed populations.

In this paper, we describe 11 polymorphic microsatellite loci in the species $H$. pomatia. These loci have also been tested on two other closely related species in the Helix genus: $H$. lucorum and $H$. lutescens.

\section{MATERIAL AND METHODS}

A representative sample consisting of 24 specimens of $H$. pomatia was collected from Bucharest, Romania $\left(44^{\circ} 23^{\prime} 7.92^{\prime \prime N}, 26^{\circ} 6^{\prime} 3.13^{\prime \prime E}\right)$. Five individuals each of $H$. lucorum and $H$. lutescens were collected from Târgu Jiu, Gorj County, Romania $\left(45^{\circ} 2^{\prime} 18.42^{\prime \prime} \mathrm{N}\right.$,

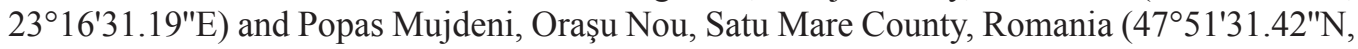

Genetics and Molecular Research 15 (3): gmr.15038817 
$23^{\circ} 14^{\prime} 39.18 \mathrm{E}$ ), respectively. All collected individuals were preserved in $96 \%$ ethanol. Total genomic DNA was isolated from foot muscle tissue using the ISOLATE II Genomic DNA Kit (Bioline, London, UK), according to producer specifications.

Microsatellite-enriched genomic libraries were developed using eight probes (TG, TC, AAC, AAG, AGG, ACG, ACAT, and ACTC). This highly enriched library was sequenced using 454 GS-FLX Titanium (Roche Diagnostics, Risch-Rotkreuz, Switzerland) pyrosequencing technologies, following the protocol described by Malausa et al. (2011). The QDD software was used to validate the best primer pairs for each microsatellite DNA region (Meglécz et al., 2010).

Software-validated primer pairs were tested for successful PCR amplification on a sample of four individuals of $H$. pomatia. Loci that yielded products of the expected size were further tested for polymorphism. After the optimization of PCR for the polymorphic primer pairs, the sampled $H$. pomatia population was genotyped. The PCR genotyping reaction was performed in a $5-\mu \mathrm{L}$ total volume containing approximately $10 \mathrm{ng}$ DNA template, $0.5 \mu \mathrm{L}$ $10 \mathrm{X} \mathrm{NH}_{4}$ Reaction Buffer [670 mM Tris- $\mathrm{HCl}\left(\mathrm{pH} 8.8\right.$ at $\left.25^{\circ} \mathrm{C}\right), 166 \mathrm{mM}\left(\mathrm{NH}_{4}\right)_{2} \mathrm{SO}_{4}, 4.5 \%$ Triton $^{\circledR}-\mathrm{X}-100,2 \mathrm{mg} / \mathrm{mL}$ gelatin], 2-2.5 $\mathrm{mM} \mathrm{MgCl}_{2}$ (see Table 1 for details regarding each locus), $0.1 \mathrm{mM}$ each dNTP, $0.05 \mu \mathrm{M}$ each primer (one of the primers was M13 tailed), 0.02 $\mu \mathrm{M}$ IRD700 or IRD800-labeled M13 primer, and 0.5 U Taq DNA polymerase (Rovalab $\mathrm{GmbH}$, Teltow, Germany). The PCR conditions used were as follows: an initial denaturation step at $95^{\circ} \mathrm{C}$ for $2 \mathrm{~min}$, followed by $30-35$ cycles of denaturation at $95^{\circ} \mathrm{C}$ for $30 \mathrm{~s}$, annealing at a specific temperature for each locus (see Table 1) for $30 \mathrm{~s}$ and extension at $72^{\circ} \mathrm{C}$ for $30 \mathrm{~s}$, followed by a final extension step at $72^{\circ} \mathrm{C}$ for $5 \mathrm{~min}$. The genotyping process was performed on an LI-COR 4300L genetic analyzer (LI-COR Biosciences, Nebraska, USA) and the Saga ${ }^{\mathrm{GT}}$ v3.1 software package was used for scoring alleles.

The loci were also tested on several individuals of H. lucorum and H. lutescens using the same PCR conditions as described for H. pomatia. GenAlEx v6.501 (Peakall and Smouse, 2006; 2012) was used to test for Hardy-Weinberg equilibrium at each locus and to estimate the number of alleles $\left(N_{\mathrm{A}}\right)$, along with observed $\left(H_{\mathrm{O}}\right)$ and expected heterozygosity $\left(H_{\mathrm{E}}\right)$. The presence of null alleles, large allele dropout, and scoring errors due to stuttering was tested using MICRO-CHECKER v2.2.3 (Van Oosterhout et al., 2004). Linkage disequilibrium tests were carried out using GENEPOP v4.2 (Raymond and Rousset, 1995; Rousset, 2008).

\section{RESULTS AND DISCUSSION}

From the enriched library, a total of 233 sequences containing microsatellite motifs were obtained. We tested 123 primer pairs in PCR and selected 40 primer pairs that provided constant amplification with a PCR product of expected size. A total of 11 polymorphic loci were successfully genotyped in all samples of $H$. pomatia.

The microsatellite loci were polymorphic, with a number of alleles per locus ranging from 3 to 13 (Table 1). The observed and expected heterozygosity values ranged from 0.458 to 0.917 for $H_{\mathrm{O}}$ and between 0.379 and 0.884 for $H_{\mathrm{E}}$, with a mean of $0.712 \pm 0.043$ (SE) and $0.667 \pm 0.043(\mathrm{SE})$, respectively. No departure from the Hardy-Weinberg equilibrium or linkage disequilibrium was observed following Bonferroni correction. The results of the MICRO-CHECKER testing showed no evidence for large allele dropout, null alleles, or scoring errors due to stuttering.

Genetics and Molecular Research 15 (3): gmr.15038817 
Table 1. Ten polymorphic microsatellites for Helix pomatia and their genetic diversity, estimated in a native population from Bucharest (Romania).

\begin{tabular}{|c|c|c|c|c|c|c|c|c|c|}
\hline \multirow[t]{2}{*}{ Locus } & \multirow[t]{2}{*}{ Primer sequence $\left(5^{\prime}-3^{\prime}\right)$} & \multirow{2}{*}{$\begin{array}{c}\text { GenBank } \\
\text { accession No. }\end{array}$} & \multirow{2}{*}{$\begin{array}{l}\text { Repeat } \\
\text { motif }\end{array}$} & \multirow{2}{*}{$\begin{array}{l}\text { Annealing } \\
\text { temp. }\left({ }^{\circ} \mathrm{C}\right)\end{array}$} & \multirow{2}{*}{$\begin{array}{l}\mathrm{MgCl}_{2} \\
(\mathrm{mM})\end{array}$} & \multicolumn{4}{|c|}{ Bucharest ( $\mathrm{N}=24$ individuals) } \\
\hline & & & & & & $N_{\mathrm{A}}$ & $\mathrm{Ho}_{\mathrm{o}}$ & $H_{\mathrm{E}}$ & pHWE \\
\hline HP 50 & $\begin{array}{l}\text { F: CATCTTGGCCGTCAGTAAG } \\
\text { R: GATAGACGCTAATCGCAGGC }\end{array}$ & KU198449 & (GTT) 8 & 53 & 2 & 8 & 0.708 & 0.763 & 0.450 \\
\hline HP 97 & $\begin{array}{l}\text { F: TATAAGTGCAGCACCTTGCG } \\
\text { R: GGGTGCCTATTACCCGATTT }\end{array}$ & KU198450 & $(\mathrm{ACTG})_{10}$ & 49 & 2 & 6 & 0.500 & 0.521 & 0.144 \\
\hline HP 186 & $\begin{array}{l}\text { F: TGCCTGTTGGAGCAGAAATA } \\
\text { R: ATGCATTATAAAGGCGTGGG }\end{array}$ & KU198451 & $(\mathrm{TC})_{14}$ & 50 & 2 & 13 & 0.833 & 0.884 & 0.586 \\
\hline HP 207 & $\begin{array}{l}\text { F: TGACAGTGACAAAGACACAGAGA } \\
\text { R: TCAAATAGGGACCAGGATCG }\end{array}$ & KU198452 & $(\mathrm{CAGA})_{10}$ & 50 & 2 & 7 & 0.833 & 0.815 & 0.318 \\
\hline HP 228 & $\begin{array}{l}\text { F: GTACGTCACAGGAGGGCAAT } \\
\text { R: GGTGTTCTAGCCAGCCACTC }\end{array}$ & KU198453 & $($ TGT) 6 & 57 & 2 & 3 & 0.708 & 0.551 & 0.075 \\
\hline HP 458 & $\begin{array}{l}\text { F: TGTGCTGCACCGTCAACTA } \\
\text { R: TTCCCTACCCAAGCTCAGAA }\end{array}$ & KU198454 & $(\mathrm{CA})_{7}$ & 51 & 2.5 & 10 & 0.833 & 0.749 & 0.162 \\
\hline HP 500 & $\begin{array}{l}\text { F: GGATGGAGAGAATACGCGAG } \\
\text { R: AAGCGTGGCAAACACTCAG } \\
\end{array}$ & KU198455 & $(\mathrm{GT})_{7}$ & 55 & 2 & 5 & 0.625 & 0.694 & 0.548 \\
\hline HP 503 & $\begin{array}{l}\text { F: TGCTGCACGTGACATAACAA } \\
\text { R: CAGCATGGGCTAGAAGAAGG }\end{array}$ & KU198456 & $(\mathrm{TCC})_{5}$ & 52 & 2.5 & 4 & 0.917 & 0.709 & 0.910 \\
\hline HP 535 & $\begin{array}{l}\text { F: GGGAGCTTGTGTCTAATGGG } \\
\text { R: GAGATATCCGAGGGCAATGA }\end{array}$ & KU198457 & $(\mathrm{AGT})_{5}$ & 56 & 2 & 3 & 0.458 & 0.379 & 0.546 \\
\hline HP 558 & $\begin{array}{l}\text { F: TATTCGCTGACACAGGAACG } \\
\text { R: CCTGGTTGTCTAATCGGCTC }\end{array}$ & KU198458 & $(\mathrm{GACT})_{5}$ & 52 & 2.5 & 5 & 0.667 & 0.622 & 0.668 \\
\hline HP 612 & $\begin{array}{l}\text { F: CACCAACTCACTCCCCACTT } \\
\text { R: TGAATGATTAAATAGACAGAATGAAAG }\end{array}$ & KU198459 & $(\mathrm{TTCA})_{6}$ & 55 & 2 & 5 & 0.750 & 0.653 & 0.215 \\
\hline
\end{tabular}

$\mathrm{N}$ - number of individuals, $N_{\mathrm{A}}$ - number of alleles, $H_{\mathrm{O}}$ and $H_{\mathrm{E}}$ - observed and expected heterozygosities, pHWE - P values for Hardy-Weinberg equilibrium test after Bonferroni correction for multiple tests $(k=11)$.

Given the fact that microsatellite markers are a very useful tool in population genetics studies, we also tested the cross-amplification of these newly developed microsatellite loci in two other helicid species, H. lucorum and H. lutescens (Table 2).

Table 2. Size ranges (bp) for alleles of the isolated loci in Helix pomatia $(\mathrm{N}=24)$, H. lucorum $(\mathrm{N}=5)$, and H. lutescens $(\mathrm{N}=5)$.

\begin{tabular}{l|c|c|c}
\hline Locus & H. pomatia & H. lucorum & H. lutescens \\
\hline HP 50 & $134-170$ & $140-158(3)$ & 173 \\
\hline HP 97 & $117-181$ & 133 & 133 \\
\hline HP 186 & $142-182$ & $164-196(4)$ & $174-194(3)$ \\
\hline HP 207 & $197-229$ & - & $205-219(3)$ \\
\hline HP 228 & $168-174$ & $165-174(4)$ & 165 \\
\hline HP 458 & $130-152$ & $132-134(2)$ & $146-166(4)$ \\
\hline HP 500 & $114-126$ & 116 & 112 \\
\hline HP 503 & $121-130$ & $187-205(2)$ & - \\
\hline HP 535 & $175-181$ & $143-147(2)$ & 184 \\
\hline HP 558 & $143-159$ & 167 & 155 \\
\hline HP 612 & $151-167$ & $171-175(2)$ \\
\hline
\end{tabular}

The total number of alleles for the cross-amplifications is indicated in parentheses. A dash indicates no PCR product.

The small sample sizes of $H$. lucorum and $H$. lutescens used in the cross-amplification tests could be the reason for the limited number of observed alleles. Further studies on larger numbers of individuals in these two species should be undertaken to assess polymorphism levels and the usefulness of these microsatellite loci.

$H$. pomatia is an intensively commercialized species, and is consumed mostly in the Mediterranean region. Although there are farms that grow these snails for consumption, they are also collected from the wild in some European regions; this may eventually threaten the existence of wild populations of this species. Currently, although wild populations are 
abundant and stable in most of the snail's native area, there are also some European Union countries in which the species is protected (e.g., the United Kingdom, Denmark, the Czech Republic, and Germany).

Population genetic studies can serve as a baseline for the protection of threatened populations and subpopulations present in regions where this species is rare. The microsatellite markers described in this study should facilitate the identification of populations of conservation concern, thus allowing informed decision-making when preparing conservation plans.

\section{Conflicts of interest}

The authors declare no conflict of interest.

\section{ACKNOWLEDGMENTS}

Research supported by the Romanian Executive Agency for Financing Education, Higher Research Development and Innovation - UEFISCDI (Grant \#113/2014, code: \#PN-IIPT-PCCA-2013-4-1489). We wish to thank Dr. Angela Petrescu for providing the H. lutescens specimens.

\section{REFERENCES}

Grossu A (1983). Gastropoda Romaniae, 4, Ordo Stylommatophora, Suprafamiliile: Arionacea, Zonitacea, Ariophantacea şi Helicacea. Edit. Litera Publishing House, Bucureşti (in Romanian).

Korábek O, Juřičková L and Petrusek A (2014). Ressurecting Helix straminea, a forgotten escargot with trans-Adriatic distribution: first insights into the genetic variation within the genus Helix (Gastropoda: Pulmonata). Zool. J. Linn. Soc. 171: 72-91. http://dx.doi.org/10.1111/zoj.12122.

Korábek O, Petrusek A, Neubert E and Juřičková L (2015). Molecular phylogeny of the genus Helix (Pulmonata: Helicidae). Zool. Scr. 44: 263-280. http://dx.doi.org/10.1111/zsc.12101.

Malausa T, Gilles A, Meglécz E, Blanquart H, et al. (2011). High-throughput microsatellite isolation through 454 GS-FLX Titanium pyrosequencing of enriched DNA libraries. Mol. Ecol. Resour. 11: 638-644. http://dx.doi.org/10.1111/ j.1755-0998.2011.02992.x.

Meglécz E, Costedoat C, Dubut V, Gilles A, et al. (2010). QDD: a user-friendly program to select microsatellite markers and design primers from large sequencing projects. Bioinformatics 26: 403-404. http://dx.doi.org/10.1093/ bioinformatics/btp670.

Mumladze L, Tarkhnishvili D and Murtskhvaladze M (2013). Systematics and evolutionary history of large endemic snails from the Caucasus (Helix buchii and H. goderdziana) (Helicidae). Am. Malacol. Bull. 31: 225-234. http://dx.doi. org/10.4003/006.031.0202.

Neubert E (2011). Helix pomatia. The IUCN Red List of Threatened Species 2011: e.T156519A4957463. Available at http://dx.doi.org/10.2305/IUCN.UK.2011-1.RLTS.T156519A4957463.en. Accessed November 23, 2015.

Peakall R and Smouse P (2006). GENALEX 6: genetic analysis in Excel. Population genetic software for teaching and research. Mol. Ecol. Notes 6: 288-295. http://dx.doi.org/10.1111/j.1471-8286.2005.01155.x.

Peakall R and Smouse PE (2012). GenAlEx 6.5: genetic analysis in Excel. Population genetic software for teaching and research - an update. Bioinformatics 28: 2537-2539. http://dx.doi.org/10.1093/bioinformatics/bts460.

Raymond M and Rousset F (1995). GENEPOP (version 1.2): population genetics software for exact tests and ecumenicism. J. Hered. 86: 248-249 Available at [http://jhered.oxfordjournals.org/content/86/3/248.full.pdf + html]. Accessed October 15, 2015.

Rousset F (2008). genepop'007: a complete re-implementation of the genepop software for Windows and Linux. Mol. Ecol. Resour. 8: 103-106. http://dx.doi.org/10.1111/j.1471-8286.2007.01931.x.

Van Oosterhout C, Hutchinson W, Wills D and Shipley P (2004). MICRO-CHECKER: software for identifying and correcting genotyping errors in microsatellite data. Mol. Ecol. Notes 4: 535-538. http://dx.doi.org/10.1111/j.14718286.2004.00684.x.

Genetics and Molecular Research 15 (3): gmr.15038817 
Welter-Schultes F (2012). European non-marine molluscs: a guide for species identification. Planet Poster Editions, Göttingen.

Wirth T (2000). Isolation and characterization of microsatellite loci in the land snail Helicella itala, and cross-species amplification within the family Helicidae. Mol. Ecol. 9: 501-502. http://dx.doi.org/10.1046/j.1365-294x.2000.00871-8.x.

Genetics and Molecular Research 15 (3): gmr.15038817 